\title{
Assessment of the Effect of Uncontrolled Landfill Sites on the Content of Available Forms of Selected Macro- and Microelements in Forest Soil
}

\author{
Agata Bartkowiak ${ }^{1}$ Joanna Lemanowicz ${ }^{1} \cdot$ Barbara Breza-Boruta $^{2} \cdot$ Andrzej Zieliński $^{3}$
}

Received: 6 June 2018 / Revised: 28 August 2018 / Accepted: 5 September 2018 / Published online: 11 September 2018

(c) The Author(s) 2018

\begin{abstract}
The paper presents the results of the effect of uncontrolled landfill sites located in the sandy soils of the Bydgoszcz Forest (central Poland, the Kujawy and Pomerania Province) on the content of available forms of selected macro- and microelements. Soil was sampled from the mineral surface horizon $(0-20 \mathrm{~cm})$ under three uncontrolled landfill sites (W1, W2, W3). They were the landfill spots on the surface of $20-35 \mathrm{~m}^{2}$ of different morphological composition. The control point (C) was located far from the waste landfill sites and beyond the range of their effect. Those soils were classified as Brunic Arenosols. This paper presents the arithmetic means of the results from three replications. Besides, the results of the analyses of the features investigated were exposed to the analysis of simple correlation $(P<0.05)$. Moreover, the principal component analysis (PCA) was used. The research demonstrated a significant effect of uncontrolled landfill sites on the changes in the soil reaction as well as significant changes in the content of organic carbon, available forms of phosphorus, potassium, magnesium, copper and zinc. With the analysis of variance, it was found that the soil sampled under landfill site showed a significantly highest amount of the macro- and microelements studied. The analysis of correlation confirmed a significant positive dependence between the content of available forms of all the elements analysed and the soil reaction. Two principal components (PC1 and PC2) were extracted from the available data set which accounted for a total variance of approximately $92.02 \%$.
\end{abstract}

Keywords Micro- and macroelements $\cdot$ Uncontrolled landfill sites $\cdot$ Forest soils

\section{Introduction}

A fast development of technology and changes in the contemporary world considerably affect the natural environment. Forest soils, an element of ecosystems, are of special importance for the monitoring of the natural environment.

Agata Bartkowiak

bartkowiak@utp.edu.pl

1 Department of Biogeochemistry and Soil Science, Faculty of Agriculture and Biotechnology, UTP University of Science and Technology in Bydgoszcz, 6 Bernardyńska St., 85-029 Bydgoszcz, Poland

2 Department of Microbiology and Food Technology, Faculty of Agriculture and Biotechnology, UTP University of Science and Technology in Bydgoszcz, 6 Bernardyńska St., 85-029 Bydgoszcz, Poland

3 Department of Plant Breeding and Seed Science, Faculty of Agriculture and Economics, University of Agriculture in Krakow, Łobzowska 24, 31-140 Krakow, Poland
Elements, accumulated in the surface horizons, under specific conditions can transform into soluble forms, available to plants (ground cover and tree stand). Among the elements indispensable for the adequate development of plants, you will find macro- and microelements, e.g., phosphorus, potassium, magnesium, iron, manganese, copper and zinc. Their availability in the soil environment is determined by the forms of occurrence and the mechanisms bonding them with organic or inorganic soil components. Their bioavailability is affected by the following physical and chemical soil properties: the grain size composition, the content of organic matter, $\mathrm{pH}$, sorption capacity, a redox potential as well as cation forms (Kabata-Pendias and Pendias 2001; Ashworth and Alloway 2004; Violante et al. 2010).

The amount of the waste produced increases proportionally to the increase in the standard of living of the society. The adequate and safe waste storage requires adequate relevant regulations and funds. Despite the existing waste management regulations, the waste is deposited in inadequate places. The illegal uncontrolled waste dumping 
sites, commonly referred to as "illegal waste dumps", are most often located on the edge of the forests, in roadside ditches, midfield tree plantings and in other rarely visited sites (Bielińska and Mocek-Płóciniak 2009). Illegal waste dumps pose a number of environmental threats, which is due to random uncontrolled landfill sites with various kinds of waste, including hazardous waste, with various toxic substances (Alkorta et al. 2004; Bielińska and Mocek-Płóciniak 2009; Frączek and Ropek 2011). A lack of adequate securities of illegal dumping sites results in a release of pollutions to the respective elements of the natural environment, since waste contains complex organic substances, mineral nitrogen in an ammonium form, xenobiotics, heavy metals, petroleum products and others (Ogundiran and Afolabi 2008).

The content of those substances in soil, especially in the surface layer, poses a threat to living organisms due to their long-term impact on the natural environment. They can also migrate deep down the soil profile, resulting in eutrophication of waters or they get transported considerably far. Negative effects of contamination with a phytotoxic effect are more often identified in light acid with a poorer sorption complex which dominates in the woodland areas of the north of Poland (Feng et al. 2007).

The aim of the paper has been to evaluate the effect of uncontrolled landfill sites located on sandy Brunic Arenosols of the Bydgoszcz Forest on the content of available forms of selected macro- and microelements $(\mathrm{P}, \mathrm{K}, \mathrm{Mg}, \mathrm{Zn}$, $\mathrm{Cu}$ ). The research results can be useful for monitoring the human-transformed forest ecosystems.

\section{Materials and Methods}

\section{Location of Soil Sampling}

Soil was sampled in the autumn of 2014 under three uncontrolled landfill sites in the Bydgoszcz Forest (Fig. 1), dominated by light soils with the grain size composition of sands and the soil reaction ranging from acid to strongly acid (Table 1). The soils were classified as Brunic Arenosols (IUSS Working Group WRB 2014). The forest is dominated by the habitats of fresh coniferous forest and the share of coniferous species in the tree stand accounts for more than 95\%. The prevailing tree stand species is Scots pine (Pinus sylvestris $\mathrm{L}$.). The landfill sites under study were small, $20-35 \mathrm{~m}^{2}$ in size, and showed a varied morphological composition (with unknown deposition time). They were marked as W1, W2 and W3. W1 and included: debris, ceramics, glass, plastics, scrap metal, fabrics and disposed electronic equipment. The waste characteristic for W2 included mostly plastic foil, plastic foodstuffs containers, metal pieces, car tyres, metal paint containers, glass bottles, elements of light bulbs and fluorescent lamps, whereas W3 included mostly

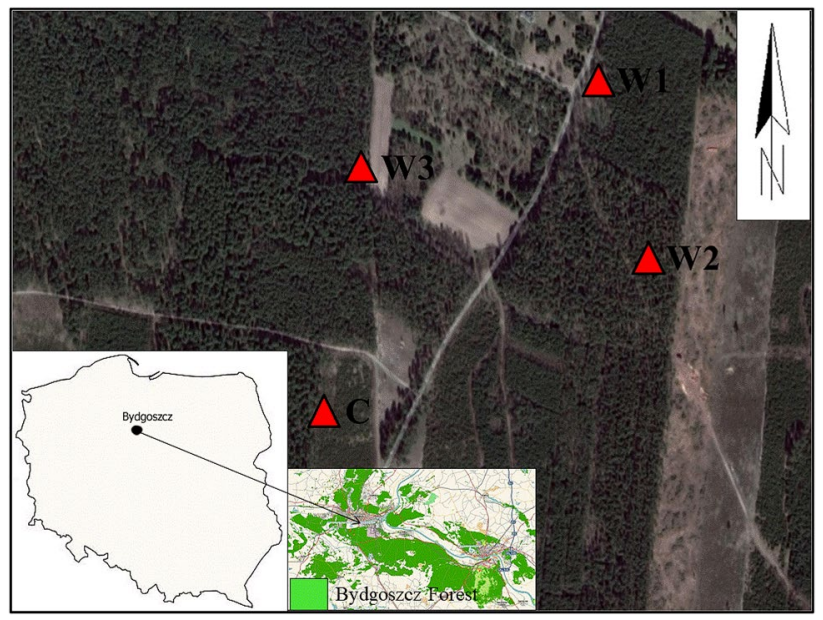

Fig. 1 Location of the study area

waste of organic origin: cut grass, leaves, tree and shrubbery post-nursing residue. The control site (C) was located far away (about $500 \mathrm{~m}$ ) from the landfill sites and their impact zone. Soil was sampled from the area similar to the landfill site area. Once the waste layer was removed, from each landfill site, using the Egner stick, ten single mineral soil samples were taken from the depth of $0-20 \mathrm{~cm}$ (PN-ISO 10381-2:2007 2007).

\section{Soil Analysis}

The soil samples were prepared compliant with the norm (PN-ISO 11464 1999) and the following were assayed for them: the grain size composition with the laser diffraction method applying analyser Masterssizer MS 2000, pH in $\mathrm{H}_{2} \mathrm{O}$ and $\mathrm{pH}$ in $1 \mathrm{M} \mathrm{KCl}$ potentiometrically (PN-ISO 10390 1997), the contents of total organic carbon (TOC) - with analyser TOC Primacs provided by Skalar; available phosphorus $\left(\mathrm{P}_{\mathrm{E}-\mathrm{R}}\right)$ spectrophotometrically-with the EgnerRiehm method-DL (PN-R-04023 1996); available potassium-with the Egner-Riehm method (PN-R-04022 1996); available magnesium - with the Schachtschabel method (PN-R-04020 1994); available forms of zinc and copperwith the method by Lindsey and Norvell (1978). The contents of $\mathrm{K}, \mathrm{Mg}, \mathrm{Zn}$ and $\mathrm{Cu}$ in extracts received following those procedures were essayed applying the ASA technique depending on the element determined in spectrometer PU 9100X (Philips). All the assays were performed in three replications; the article presents the arithmetic means of the results.

\section{Statistical Analysis}

Single-factor analyses of variance were performed in independent design, according to the fixed model, the 
Table $1 \mathrm{pH}$ and texture of soils

\begin{tabular}{|c|c|c|c|c|c|c|c|c|c|c|}
\hline \multirow[t]{3}{*}{ Objects } & \multirow{2}{*}{\multicolumn{2}{|c|}{$\mathrm{PH} \mathrm{H}_{2} \mathrm{O}$}} & \multirow{2}{*}{\multicolumn{2}{|c|}{$\mathrm{PH} \mathrm{KCl}$}} & \multicolumn{6}{|c|}{ Fractions (\%) } \\
\hline & & & & & \multicolumn{2}{|l|}{ Sand } & \multicolumn{2}{|l|}{ Silt } & \multicolumn{2}{|l|}{ Clay } \\
\hline & Min & Max & Min & Max & Min & Max & Min & Max & Min & $\operatorname{Max}$ \\
\hline $\mathrm{C}$ & 4.20 & 4.75 & 3.85 & 4.39 & 79.89 & 90.62 & 8.57 & 17.90 & 0.81 & 2.21 \\
\hline W1 & 6.74 & 8.56 & 6.54 & 8.02 & 80.50 & 90.25 & 8.81 & 18.65 & 0.85 & 1.71 \\
\hline W2 & 4.42 & 4.83 & 4.35 & 4.67 & 77.55 & 93.10 & 4.93 & 20.54 & 0.85 & 1.97 \\
\hline W3 & 6.98 & 7.34 & 6.85 & 7.30 & 79.98 & 91.25 & 7.37 & 17.67 & 0.98 & 2.35 \\
\hline
\end{tabular}

$C$ control point, $W$ dumping waste sites

homogeneity of which was confirmed with the Levene's test. The variation in the object means was defined by determining homogeneous groups based on the LSD test at the level of significance of $\alpha=0.05$. The content of available macroand microelements, Corg, the grain size composition as well as the soil reaction were evaluated with the principal component analysis (PCA), the assumptions of which were verified with the Bartlett test and Kaiser-Mayer-Olkin factor. The coefficients of linear correlation between all the variables analysed were also determined.

\section{Results and Discussion}

\section{Basic Soil Properties}

The content of organic carbon in the soil samples analysed varied depending on the soil sampling site (Table 2). Of all the soil samples, the highest value of the parameter was noted in the soil sampled under W3 where the morphological composition revealed an accumulation of organic waste. There was recorded significant difference between the content of organic carbon assayed for the control site and for W3. The key source of TOC in the control samples was a gradual accumulation of the matter from fallen tree leaves and dead ground cover. Under specific conditions, found in the layer of ecto-humus of forest soils, organic matter which, in the process of humification, gets transformed in a specific organic substance accumulates (Brogowski and Chojnicki 2013). At sites W1 and W2, due to the kind of the waste deposited, which constituted a barrier, there was no supply of fresh organic matter and, produced as a result of humification, easily water-soluble humus compounds (fulvic acids) could have leached deep down the soil profile. The rate of changes of soil organic matter depends, to much extent, on its fragmentation but also on the air-water relations, temperature and the method of use (Hamza and Anderson 2005; Slepetiene and Slepetys 2005). The household activity is the source of a considerable amount of organic waste which often constitutes a considerable share in the mass of uncontrolled landfill sites; in soil under waste, it increases the amount of organic carbon, as compared with the corresponding arable soils horizon. The differences in the composition and types of plant residue deposited at W3 contributed to neutralising the soil acidity. According to Xu et al. (2006), it was related to the degree of decomposition of plant residue, anions and cations released from it as well as the immobilisation by microorganisms.

\section{Macro- and Microelements Content and Its Relation to Other Soil Parameters}

With the analysis of variance, a significant effect of the type of waste on the content of available phosphorus in soil was found (Table 2). The highest amount of $P\left(35.76 \mathrm{mg} \mathrm{kg}^{-1}\right)$ was noted in the soil under W3. The values were tenfold higher as
Table 2 The content of organic carbon, available forms of phosphorus $(\mathrm{P})$ potassium $(\mathrm{K})$ and magnesium $(\mathrm{Mg})$

\begin{tabular}{lllll}
\hline Objects & $\begin{array}{l}\text { TOC } \\
\mathrm{g} \mathrm{kg}^{-1}\end{array}$ & $\mathrm{P}$ & $\mathrm{K}$ & $\mathrm{Mg}$ \\
\hline $\mathrm{C}$ & $8.97^{\mathrm{b}} \pm 0.035$ & $3.765^{\mathrm{c}} \pm 0.134$ & $15.15^{\mathrm{d}} \pm 0.353$ & $10.05^{\mathrm{d}} \pm 0.353$ \\
$\mathrm{~W} 1$ & $4.055^{\mathrm{c}} \pm 0.148$ & $17.95^{\mathrm{b}} \pm 0.091$ & $39.30^{\mathrm{c}} \pm 0.530$ & $61.81^{\mathrm{c}} \pm 0.855$ \\
$\mathrm{~W} 2$ & $4.77^{\mathrm{c}} \pm 0.219$ & $3.13^{\mathrm{c}} \pm 0.113$ & $46.00^{\mathrm{b}} \pm 0.141$ & $64.33^{\mathrm{b}} \pm 0.322$ \\
W3 & $22.84^{\mathrm{a}} \pm 0.863$ & $35.76^{\mathrm{a}} \pm 0.997$ & $57.31^{\mathrm{a}} \pm 0.658$ & $82.25^{\mathrm{a}} \pm 0.212$ \\
NIR $_{0.05} \mathrm{LSD}_{0.05}$ & 1.838 & 2.069 & 1.886 & 2.048 \\
\hline
\end{tabular}

Marked values in the same columns with different letter are significantly different $(P=0.05)$

Mean \pm SD standard deviation

$L S D$ least significant difference 
compared with the control soil. The significantly lowest $\mathrm{P}$ content ( $3.13 \mathrm{mg} \mathrm{kg}^{-1}$ ), similar to the control site, was reported in W2 soil where electrotechnical equipment, car tyres and fabrics prevailed. Usually, in the forest ecosystem, the content of phosphorus in soil is a deficit (Jonczak et al. 2015), and its key source is plant litter (Dziadowiec et al. 2008), which is also related to the tree species composition. The factor determining the content of available phosphorus in soil is its reaction, which was confirmed by a significant positive value of the coefficient of correlation $(r=0.932 ; P<0.05)$ (Table 4). As for the $\mathrm{pH}$ values below 6.5 , phosphorus is bonded by free $\mathrm{Fe}$ and $\mathrm{Al}$ oxides (Achat et al. 2013). There were also found significant positive correlations between the content of $\mathrm{P}$ and $\mathrm{Zn}(r=0.895 ; P<0.05)$ and $\mathrm{Cu}(r=0.897 ; P<0.05)$.

The resources of magnesium and potassium available to plants are made up of ions present in the soil solution and exchangeable cations bonded with the sorption complex. The quantity and quality of soil colloids in specific moisture conditions determine the form of the occurrence of elements and their leaching deep down the soil profile (Kobierski et al. 2011). The analysis of variance showed a significant effect of the soil sampling site on the content of available forms of potassium and magnesium (Table 2). The significantly lowest values of the elements were noted for the control, respectively, $15.15 \mathrm{mg} \mathrm{kg}^{-1}$ for potassium and $10.05 \mathrm{mg} \mathrm{kg}^{-1}$ for magnesium and the highest-in W3 soil $\left(57.31 \mathrm{mg} \mathrm{kg}^{-1}\right.$ of potassium and $82.25 \mathrm{mg} \mathrm{kg}^{-1}$ of magnesium). Both potassium and magnesium are elements which easily leach down the soil profile. Such inconsiderable amounts of potassium found in the samples from $\mathrm{C}$ site could have been due to its leaching, mostly as a result of the grain size composition of the soils analysed. In light soils with a low sorption complex capacity, leaching is higher than in heavy soils. The analysis of correlation, however, did not confirm any such dependencies. The factor determining the content of available forms of the two elements, similarly as for phosphorus, was the soil reaction. The analysis of correlation showed a significantly positive correlation between reaction $(\mathrm{pH}$ in $\mathrm{KCl})$ and the content of available forms of $\mathrm{K}(r=0.807 ; P<0.05)$ and $\mathrm{Mg}$ $(r=0.754 ; P<0.05)$.

An increased content of macroelements (e.g., phosphorus, potassium, magnesium) in soil sampled under the illegal landfill sites can cause the so-called "chemical stress", and their concentration is, to much extent, conditioned by the morphological composition of the waste dump. For example, the compounds of magnesium are used mostly as refractory and insulation material; potassium mostly in fertilisation industry or as $\mathrm{CO}_{2}$ absorbers; sulphur for the production of dyes, matches; sodium for the production of foodstuffs; while calcium-as a component-fixing building materials, mortars.

The soil, representing the agronomic category of very light and light soils, showed a varied richness in bioavailable
Table 3 The content available forms of zinc $(\mathrm{Zn})$ and copper $(\mathrm{Cu})$

\begin{tabular}{|c|c|c|}
\hline Objects & $\begin{array}{l}\mathrm{Zn} \\
\mathrm{mg} \mathrm{kg}^{-1}\end{array}$ & $\mathrm{Cu}$ \\
\hline $\mathrm{C}$ & $2.09^{\mathrm{b}} \pm 0.002$ & $0.375^{\mathrm{c}} \pm 0.035$ \\
\hline W1 & $1.90^{c} \pm 0.036$ & $0.490^{\mathrm{b}} \pm 0.019$ \\
\hline W2 & $1.57^{\mathrm{d}} \pm 0.004$ & $0.537^{\mathrm{b}} \pm 0.015$ \\
\hline W3 & $54.2^{\mathrm{a}} \pm 0.059$ & $6.36^{\mathrm{a}} \pm 0.002$ \\
\hline $\mathrm{NIR}_{0.05} \mathrm{LSD}_{0.05}$ & 0.141 & 0.052 \\
\hline
\end{tabular}

Table 4 Coefficient of linear correlation between parameters

\begin{tabular}{llllll}
\hline Variable & $\mathrm{P}$ & $\mathrm{K}$ & $\mathrm{Mg}$ & $\mathrm{Zn}$ & $\mathrm{Cu}$ \\
\hline $\mathrm{Mg}$ & - & 0.987 & - & - & - \\
$\mathrm{Zn}$ & 0.895 & - & - & - & - \\
$\mathrm{Cu}$ & 0.897 & - & - & - & - \\
$\mathrm{pH} \mathrm{KCl}$ & 0.932 & 0.807 & 0.754 & 0.972 & 0.978 \\
\hline
\end{tabular}

forms of zinc and copper (Table 3). Martinez and Motto (2000) reported on the mobility of zinc and copper depending on soil reaction and similar $\mathrm{pH}$ values below which their mobility increases, being 6.2 and 5.5. In the present study, a significant positive correlation was reported between $\mathrm{pH}$ in $\mathrm{KCl}$, and the content of forms of $\mathrm{Zn}(r=0.972 ; P<0.05)$ and $\mathrm{Cu}(r=0.978 ; P<0.05)$ extracted with the DTPA solution (Table 4). A more than 25 -fold higher $\mathrm{Zn}$ content in soil under W3, as compared with the other three sites, resulted in the correlation with $\mathrm{pH}$ being positive and so high. The correlations with zinc do not comply with the data reported in literature. An increasing soil $\mathrm{pH}$ is accompanied by a decreased concentration of zinc, which can be due to an increased bonding of the element by iron and aluminium oxides, or precipitating them to less-soluble forms (Stone and Marsalek 1999). However, Chukwuma et al. (2010) also showed a positive correlation between $\mathrm{pH}$ and $\mathrm{Zn}$ in the soils polluted with petroleum. The soils, similarly as in the present study, were not covered by vegetation. Zinc undergoes also sorption by organic substance, the intensity of which depends on the soil reaction. Under $\mathrm{pH} 5.8$, humic acids bond zinc in $60 \%$ of its cation concentration, while under the conditions of lower values, the bond almost disappears (Stone and Marsalek 1999). The analysis of correlation did not demonstrate, however, a correlation between TOC and the content of available $\mathrm{Zn}$ forms. The concentration of available forms of $\mathrm{Zn}$ and $\mathrm{Cu}$ in all the soil samples was higher from the content critical for plants, namely $0.5-0.8 \mathrm{mg} \mathrm{kg}^{-1}$ for zinc (Lindsey and Norvell 1978; Sims and Johnson 1991) and $0.4 \mathrm{mg} \mathrm{kg}^{-1}$ for copper (Karamanos et al. 1986). The significantly highest content of available forms of both microelements was found in the soil 
under W3 (Table 3). The values were many times higher than those found in the control samples. In W3, the content of available forms of zinc was very high and it reached $54.2 \pm 0.059 \mathrm{mg} \mathrm{kg}^{-1}$. In general, the plants show a high tolerance to elevated amounts of zinc in soil and the level of tolerance as compared to that metal which depends mostly on the physico-chemical properties of soil and the plant species and cultivars (Cakmak 2008; Wyszkowska et al. 2013). The tolerance of plants to high zinc contents is quite common, especially in the regions polluted with that element and the plants exposed to its high content in soils can show no symptoms of toxicity (Baran and Wieczorek 2012).

\section{The Principal Component Analysis (PCA)}

The evaluation of the principal components for the contents of selected macro- and microelements, $\mathrm{pH}$ and the clay fraction is presented in Fig. 2. The coefficients of components corresponding to each value confirmed that the first two account for more than $90 \%$ of the total variation. The directional vectors of all the variables analysed showed an inverse inclination towards the principal horizontal axis, which accounts for almost $65 \%$ of co-variation against the entire data set. Factor loadings for variable $\mathrm{P}, \mathrm{K}, \mathrm{Mg}, \mathrm{Cu}, \mathrm{Zn}$ and the reaction of soils from respective landfill sites represent a separate set of parameters determining the first component which can be referred to as "accumulative". However, the evaluated elemental composition can be negatively classified against the first component in the following order: $\mathrm{P}>\mathrm{Cu}>\mathrm{Zn}>\mathrm{K}>\mathrm{Mg}$. Very strong such dependencies were demonstrated by the soil reaction and the contents of phosphorus, copper or zinc. The vectors of those variables point to the highest positive linear dependencies allowing the allocation the most abundant homogeneous group making

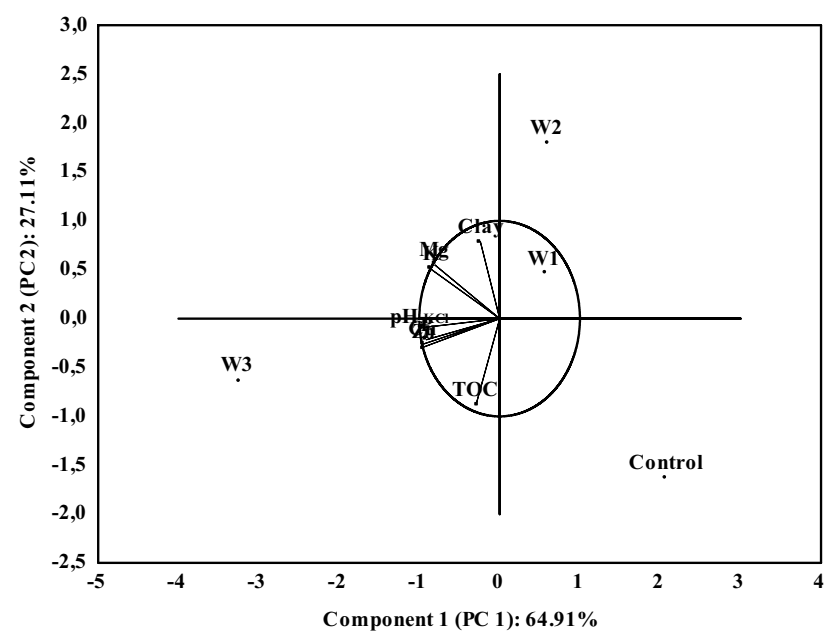

Fig. 2 Configuration of variables in the system of the first two axes $\mathrm{PC} 1$ and $\mathrm{PC} 2$ of principal components up the first principal component. The decomposition of the effects of single variables for the content of organic carbon as well as the clay fraction revealed their dominant effect on determining the second component, which accounts for about $27 \%$ of the total variance of the total variation. The content of available forms of potassium and magnesium corresponds inverse proportionally in a balanced range to both distinguished principal components. Both elements also show a positive correlation with the soil reaction. However, the projections of vectors for the content of TOC and clay fraction against the axis representing the first principal component point to a weak negative correlation and a limited effect of the "accumulative" component. The centroid distance for the clay fraction confirms the lowest share in determining the variation of the properties of landfill sites and the control site.

The physico-chemical properties of the soil sampled under W3 most corresponded to the variables determining the first component. The contents of available forms of $\mathrm{Cu}$ and $\mathrm{Zn}$, as well as phosphorus or soil reaction, were closely related to the soil sampling location under W3. W1 and W2 showed a positive orientation in space in reference to the second principal component and generated the highest variation in the content of clay fraction. The pattern of the value of clay fraction is the closest for the soils sampled under landfill site W2. In the samples analysed from that site, the highest factor loading for that variable was noted. The opposite dependence was recorded for the soil sampled from W1 and W2 for the content of organic carbon, which points to their inconsiderable share in defining its variance.

However, the occurrence of specific variation in TOC in the furthest habitats was found. Negatively oriented against the second principal component, the content of total organic carbon (TOC) was in the same range represented in the samples from the control site-with an inconsiderable content of $\mathrm{Cu}$ and $\mathrm{Zn}$ as well as W3, showing the highest concentration of those elements. The opposite orientation of factor loadings of the content of clay fraction against the control site points to its lowest share in defining the variation at the control site. Of the sampling sites specified in the study to evaluate the contamination of soils, the conditions in W1 represented the values most similar to the average, in comparison to those on the other sites. The distance between that site and the beginning of the principal components system points to a strong effect of all the variables analysed.

\section{Conclusions}

1. Uncontrolled landfill sites in the Bydgoszcz Forest showed a significant effect on the soil reaction and on the changes in the content of organic carbon. 
2. The analysis of variance identified a significant effect of the type of waste deposited on all studied chemical properties. The highest accumulation of both macro- and microelements was found in the soil under landfill site W3 accumulating organic waste of plant origin. The analysis of correlation confirmed a significant positive dependence between soil reaction and the content of available forms of $\mathrm{P}, \mathrm{K}, \mathrm{Mg}, \mathrm{Cu}$ and $\mathrm{Zn}$.

3. The existing uncontrolled landfills significantly affect physicochemical properties and the content of macroelements and micronutrients in soils. The landfill sites are a potential threat to the natural environment. With that in mind, one shall continue the applicable monitoring studies to evaluate the risk of changes in the forest ecosystems transformed by the man.

Acknowledgements The research was performed as part of research project BS 2/17 of the UTP University of Science and Technology in Bydgoszcz, the Faculty of Agriculture and Biotechnology, the Department of Soil Science and Soil Protection.

Open Access This article is distributed under the terms of the Creative Commons Attribution 4.0 International License (http://creativeco mmons.org/licenses/by/4.0/), which permits unrestricted use, distribution, and reproduction in any medium, provided you give appropriate credit to the original author(s) and the source, provide a link to the Creative Commons license, and indicate if changes were made.

\section{References}

Achat DL, Bakker MR, Augusto L, Derrien D, Gallegos N, Lashchinskiy N, Milin S, Nikitich P, Raudina T, Rusalimova O, Zeller B, Barsukov P (2013) Phosphorus status of soils from contrasting forested ecosystems in southwestern Siberia: effects of microbiological and physicochemical properties. Biogeosciences 10:733752. https://doi.org/10.5194/bg-10-733-2013

Alkorta I, Hernandez-Allica J, Beccerril JM, Amezaga I, Albizu I, Garbisu C (2004) Recent findings on the phytoremediation of soils contaminated with environmentally toxic heavy metals and metalloids such as zinc, cadmium, lead, and arsenic. Rev Environ Sci Biotechnol 3:71-90

Ashworth DJ, Alloway BJ (2004) Soil mobility of sewage sludgederived dissolved organic matter, copper, nickel and zinc. Environ Pollut 127:137-144. https://doi.org/10.1016/S0269 -7491(03)00237-9

Baran A, Wieczorek J (2012) Content of zinc in the different elements of the environment in zone of potential impact galvanizing. Proc ECOpole 6(1):193-198. https://doi.org/10.2429/ proc.2012.6(1)025 (In Polish)

Bielińska EJ, Mocek-Płóciniak A (2009) Impact of uncontrolled waste dumping on soil chemical and biochemical properties. Arch Environ Prot 35(3):101-107

Brogowski Z, Chojnicki J (2013) Distribution of organic matter and nitrogen in the particle size fractions of genetic horizons in Dystric Cambisols in the Kabacki Forest. Sylwan 157(6):470-480 (In Polish)
Cakmak I (2008) Enrichment of cereal grains with zinc: agronomic or genetic biofortification? Plant Soil 302(1):1-17. https://doi. org/10.1007/s11104-007-9466-3

Chukwuma MC, Eshett ET, Onweremadu EU, Okon MA (2010) Zinc availability in relation to selected soil properties in a crude oil polluted eutrictropofluvent. Int J Environ Sci Techol 7(2):261-270

Dziadowiec H, Jonczak J, Czarnecki A, Kacprowicz K (2008) Mass, dynamics and chemical composition of litter fall in age differentiated plantations of poplar clone Hybryda 275. Soil Sci Annu 58(3/4):68-77 (in Polish)

Feng N, Dagan R, Bitton G (2007) Toxicological approach for assessing the heavy metal binding capacity of soils. Soil Sediment Contam 16(5):451-458. https://doi.org/10.1080/15320380701490226

Frączek K, Ropek D (2011) Municipal waste dumps as the microbiological threat to the natural environment. Ecol Chem Eng 18(1):93-110

Hamza MA, Anderson WK (2005) Soil compaction in croping systems. A review of the nature, causes and possible solutions. Soil Tillage Res 82:121-145. https://doi.org/10.1016/j.still.2004.08.009

IUSS Working Group WRB (2014) World Reference Base for Soil Resources 2014, vol 106. World Soil Resources Reports. FAO, Rome

Jonczak J, Simansky V, Polláková N (2015) Content and profile distribution of phosphorus fractions in arable and forest Cambic Chernozems. Sylwan 159(11):931-939

Kabata-Pendias A, Pendias P (2001) Trace elements in soils and plants, 3rd edn. CRC Press, Florida. ISBN 0-8493-1575-1

Karamanos RE, Kruger GA, Stewart JWB (1986) Copper deficiency in cereal and oilseed crops in northern prairie Canadian soils. Agron J 78:317-323

Kobierski M, Długosz J, Bartkowiak A (2011) Sorption complex of selected soils of the Drawskie Lakeland. J Elementol 16(3):397-405

Lindsey WL, Norvell WA (1978) Development of a DTPA soil test for zinc, iron, manganese, copper. Soil Sci Soc Am J 42:421-428

Martinez CE, Motto HL (2000) Solubility of lead, zinc and copper added to mineral soils. Environ Pollut 107:153-158

Ogundiran OO, Afolabi TA (2008) Assessment of the physicochemical parameters and heavy metal toxicity of leachates from municipal solid waste open dumpsite. Int J Environ Sci Technol 5(2):243250. https://doi.org/10.1007/BF03326018

PN-ISO 10381-2:2007 (2007) Soil quality. Sampling—part 2: guidance on sampling techniques. Polish Standards Committee, Warszawa

PN-ISO 10390 (1997) Chemical and agricultural analysis. Determining soil pH. Polish Standards Committee, Warsaw

PN-ISO 11464 (1999) Soil quality. Preliminary preparation of samples for physico-chemical analysis. Polish Standards Committee, Warszawa (in Polish)

PN-R-04020 (1994) Chemical and agricultural analysis. Determination of the content available magnesium. Polish Standards Committee, Warszawa (In Polish)

PN-R-04022 (1996) Chemical and agricultural analysis. Determination of the content available potasium in mineral soils. Polish Standards Committee, Warszawa (In Polish)

PN-R-04023 (1996) Chemical and agricultural analysis. Determination of the content available phosphorus in mineral soils. Polish Standards Committee, Warszawa (In Polish)

Sims J, Johnson G (1991) Micronutrient soil tests. In: Mortverdt J, Cox F, Shuman L, Welch R (eds) Micronutrients in agriculture. Soil Science Society of America, Fitchburg, pp 427-476

Slepetiene A, Slepetys J (2005) Status of humus in soil under various long-term tillage systems. Geoderma 127:207-215. https://doi. org/10.1016/j.geoderma.2004.12.001

Stone M, Marsalek J (1999) Trace metal composition and spetiation in street sediment. Water Air Soil Pollut 87:149-169 
Violante A, Cozzolino V, Perelomov L, Caporale AG, Pigna M (2010) Mobility and bioavailability of HM and metalloids in the soil. J Soil Sci Plant Nutr 10(3):268-292. https://doi.org/10.4067/S0718 $-95162010000100005$

Wyszkowska J, Borowik A, Kucharski M, Kucharski J (2013) Effect of cadmium, copper and zinc on plants, soil, microorganisms end soil enzymes. J Elementol 4:769-796. https://doi.org/10.5601/ jelem.2013.18.4.455

Xu JM, Tang C, Chen ZL (2006) The role of plant residues in $\mathrm{pH}$ change of acid soils differing in initial $\mathrm{pH}$. Soil Biol Biochem 38:709-719. https://doi.org/10.1016/j.soilbio.2005.06.022 